Review Article

\title{
Chemistry, Pharmacology and Ethnomedicinal Uses of Helianthus annuus (Sunflower): A Review
}

\author{
Tasneem Bashir*, Zia-Ur-Rehman Mashwani, Kulsoom Zahara, \\ Shakeela Haider, Shaista Tabassum and Mudrikah \\ 1 Department of Botany, PMAS Arid Agriculture University Rawalpindi, Pakistan \\ *Corresponding author's email: tasneembashir34@yahoo.com
}

\section{Citation}

Tasneem Bashir, Zia-Ur-Rehman Mashwani, Kulsoom Zahara, Shakeela Haider, Shaista Tabassum and Mudrikah. Chemistry, Pharmacology and Ethnomedicinal Uses of Helianthus annuus (Sunflower): A Review. Pure and Applied Biology. Vol. 4, Issue 2, 2015, pp 226-235

Received: 25/03/2015

Revised: 13/04/2015

Accepted: 20/04/2015

\section{Abstract}

Helianthus annuus commonly known as "Sunflower" is a well-known plant in India and Pakistan. It is native to North America. It is use in ethnomedicine for treating a number of disease conditions which include heart disease, bronchial, laryngeal and pulmonary affections, coughs and colds and in whooping cough. Helianthus annuus contains various bioactive compounds which include phenol, terpene compounds, carbohydrates, flavanoids, tannins, alkaloids, saponins, steroids, fixed oil and active proteins all of these contribute to its remedial properties. H. апnиus is pharmacologically studied for various activities including gantiinflammatory, anti-oxidant, antitumor, antiasthmatic, antigen, antipyretic, astringent, antihypoglycemic effect, antifungal activities, cathartic, diuretic, stimulant, vermifuge, vulneray purposes and antimicrobial activities. The analysis of the phytochemical constituents, uses and pharmacological properties of $H$. annuus was carried out by using different sources such as medicinal plant databases, ethnobotanical and ethnopharmacological books and different published papers. This review presents a reasonable study of the chemical; nutritional and pharmacological properties of $H$. аппииs.

Keywords: Helianthus annuиs; Chemistry; Nutritional value; Medicinal uses

\section{Introduction}

From the ancient time, plants are the main source of treatment and nowadays they are focal point of medicinal source not only in developing countries, but also in developed countries where modern medicines are predominantly used. It is analyze that till to now 75-90\% of the world population depends on plants and plants extracts which act as a primary source of health care [1]. This wide spread use of plant extracts in treatment of diseases lead to increase an interest in the identification of active compounds which give the extracts their curative potential. The Sunflower (Fig. 1) is a native of North America [2]. The sunflower is the core of medicinal values which is used as food and medicine worldwide. H. annuus is cultivated basically for its seeds, which give the world's second most important source of edible oil. The seed oil, shoots, and herb tincture is 
employing for anti-inflammatory, antioxidant, antitumor, antiasthmatic, antigen, antipyretic, astringent, antihypoglycemic effect, cathartic, diuretic, stimulant, vermifuge, antimicrobial activities and vulnerary purposes, other parts of the plant, the petioles and young flowers are use as savory delicacies. The use of yellow petals as coloring agents gives its new eventual in cosmetic industry [3].

\section{Taxonomy}

Taxonomy of $H$. annus is as kingdom: plantae, Division: angiospermae, Subdivision: eudicots, Class: asteroids, Order: Asterales, Family: Asteraceae, Subfamily: Helianthoideae, Scientific Name: Helianthus annuus L. [3].

\section{Botanical description:}

Helianthus annuus L. is a stiff, plump and common annual plant 1-3 meters high. It has initially tap roots but when plant become mature then develops large, fibrous and lateral roots. Stems of this plant are 1-6ft tall, hispid, round and unbranched. Stem length is determined by the number of internodes. Leaves are arranged in such a way that lowers leaves mostly opposite along stem and upper leaves alternate along stem. Leaves are mostly ovate shaped and mostly $4-20 \mathrm{~cm}$ long and $3-15 \mathrm{~cm}$ wide or more, apex acute to abruptly auminate and margins are serrate. Inflorescence of this plant is a capitulum composite heads, solitary at terminal of peduncle or terminal on a branch or axillary, ray and disc florets present. Ray flowers are sterile, 0.6-1.6 inch long, ligules yellow. Disc flowers perfect, corolla lobes 5, 0.2-0.3 inch long,tubular and purple brown to yellow. Pappus is 2 and deciduous and ovary is inferior in disc flower. Fruit of $H$. annuus is an achene. Achenes vary from 7 to $25 \mathrm{~mm}$ in length and 14 to13 $\mathrm{mm}$ in width [4].

The head of sunflower is made up of 1,000 to 2,000 individual flowers which are connected at a common receptacle. It has ray flowers which are ligulated around boundry and are without stamens and pistils and the other flowers are perfect. Anthesis initiates at the periphery and move toward head. In temperate regions sunflower require about 11 days from planting to emergence, 33 days require from emergence to head formation, 27 days from head to first anther formation and 8 days from first to last anther for maturity from last anther to crop 30 days need. Varieties differences occur in maturity occur due to changes in vegetative period before the head become able to seen [5].

\section{Nutritional Benefits}

Sunflower seed mainly grown for oil is a source of vegetable proteins [6]. The different health advantages of sunflower seeds credited to the high levels of polyunsaturated and monounsaturated fats, phytosterols, tochopherols, protein, copper, folates, iron, zinc and vitamin B. Sunflower oil contains four important fatty acids which are palmitic, stearic, oleic, and linoleic [7-9]. Sunflower oil is basically triglycerides (fats), commonly derived from the fatty acids linoleic acid and oleic acid. Different constituents of sunflower oil are lecithin, tochopherols, carotenoids and waxes. This oil is light in taste and colour and has high vitamin $E$ content. It is a mixture of monosaturated and polysaturated fats with little saturated fat levels [10].

\section{Chemistry}

H. annuus contains different biologically active compounds (Table 1) that exhibit physiological effects which can be responsible for its curative potential in a broad range of disease conditions. These non-nutritive chemicals are known as phytochemicals and are naturally produced by the plant as defense against biotic and abiotic stresses. Most researchers used standard methods for screening of phytochemicals in $H$. annuus Allelochemicals found in leaves, stems and roots of $H$. annuus. The important chemicals 
derived from $H$. annuus are flavonoids, flavanoids, carbohydrates, tannins, saponins, alkaloids, phytosterols, active proteins and fixed oils [11]. The composition of the seed of sunflower is as proteins, peptides, amino acids and other non-protein nitrogen, carbohydrates, lipids, fatty acids, palmitic acid, olic acid, linoleic acid, tochophherol, carotenoids, vitamin, chlorogenic acid, quinic acid, caffeic acid, total minerals potassium, sulphur, phosphorus, calcium, magnesium and sodium [12].

\section{Carbohydrate}

Polysaccharides which are non-starch obtained from sunflower ( $H$. annuus L.) extracts by delignification of the related cell wall materials which were sub fractionated by graded ethanol precipitation, adsorption chromatography and size exclusion and by chronological alkaline extraction [13]. The methanolic seeds extract of $H$. annuus L. show that the plant contain significant amount of carbohydrates [14].

\section{Tannins}

Tannins are reported in $H$. annuus and it is analyzed that contain an oleic acid, alkaloid, tannins, fixed oils and simple phenolic compound [15].

\section{Phenols}

Phenols are isolated from $H$. annuus Florets of sunflower are rich source of dietary fiber, Fe and phenols [16].

\section{Terpene compounds}

From the aerial parts of $H$. annuus an entkaurane glycoside named helikauranoside A (Fig. 2) are analyze along three known compounds which are grandifloriacid, paniculoside and ent-kaurane-type diterpenoids: (-) kaur-16-en-19-oic acid [17]. A new germacranolide with amethylene-y-lactone moiety, the heliangolideniveusin B and its ethoxy derivative (Fig3) are isolated by ethanolic extract and their structures elucidated by spectroscopic methods and two sesquiterpene are derived from the leaves and stem [18, 19].

\section{Allelochemicals}

Allelochemicals are analyzed in leaves, roots and stems of sunflower by using thin layer chromatography for alkaloids and spectrophotometry for flavonoids and phenols [20].

\section{Flavonoids}

Five flavanoids (Fig 4) which include chalconeskukulcanin $\mathrm{B}$, helianone $\mathrm{A}$, the flavanones heliannones $\mathrm{B}$ and $\mathrm{C}$ and flavonoltambulin are isolate from $H$. annuus L. [21, 22].

\section{Proteins}

Some light colored proteins are derived from $H$. annuus. Four tochopherols $(\alpha, \beta, \gamma$ and $\delta)$ isomers are also present in sunflower seed oil bodies. It contains helianthinin as globulin [23].

A proteinaceous competitive inhibitor of lipase is isolated from the seeds of $H$. annuus L. [24]. A 16-kDa protein, SAP16 is also isolated [25].

\section{Sunflower oil}

Sunflower seeds contain high amount of vitamin $E$ rich oil. This oil is very beneficial for human due to high amount of vitamin $E$ and low amounts of saturated fat. The most active component of this oil is $\alpha$-tocopherol which is an antioxidant that protect against ROS (Reactive oxygen species). This oil is largely utilized by food industry. This oil can withstand at high cooking temperature. Sunflower oil is use as a lubricant and cosmetic ingredient. It is also used as a vegetable oil [26].

Caffeic acid, chlorogenic acid and dicaffeoylquinic acid

Caffeic acid (Fig. 5), chlorogenic acid and dicaffeoylquinic acid are isolated from aqueous methanol extract of seeds of sunflower

[11]. 

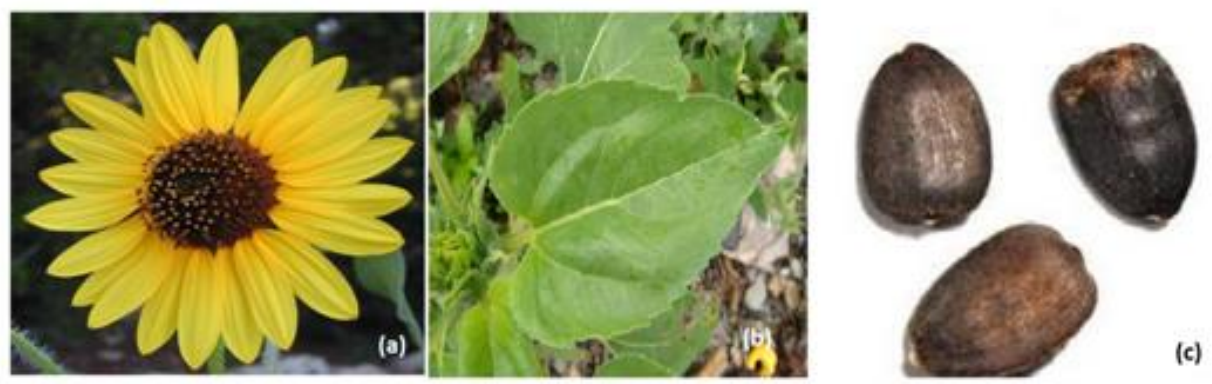

Figure 1: Helianthus annuus Flower (a), Leaves (b) and seeds (c)

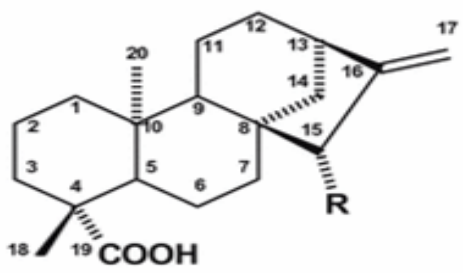

$1 \mathrm{R}=\mathrm{H}$

2 R=OAng

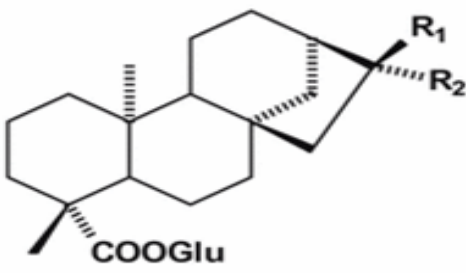

$3 \quad \mathrm{R}_{1}=\mathrm{CH}_{2} \mathrm{OH} \quad \mathrm{R}_{2}=\mathrm{OH}$

$4 \quad \mathrm{R}_{1}=\mathrm{CH}_{2} \mathrm{OH} \quad \mathrm{R}_{2}=\mathrm{H}$

Figure 2: Chemical Structure of 1). (-)-kaur -16-en-19-oic acid 2). Grandifloric acid 3). Paniculoside IV and 4). Helikauranoside A (Dwivedi and sharma, 2014).

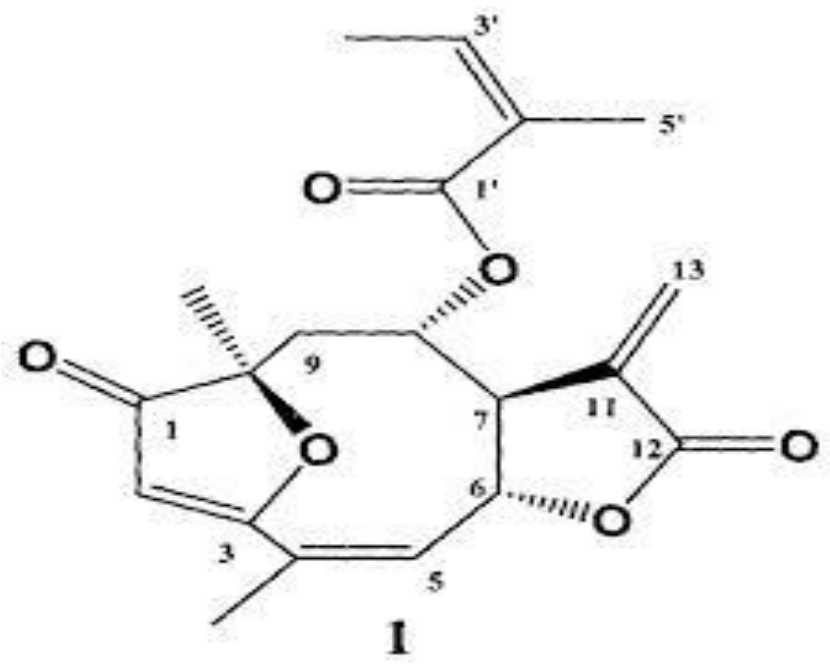

Figure 3: Heliangolide derivatives 


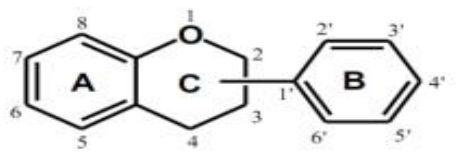

Flavonoid backbone<smiles>O=c1c(-c2ccccc2)coc2ccccc12</smiles>

Isoflavones<smiles>O=C(/C=C/c1ccccc1)c1ccccc1</smiles><smiles>O=c1cc(-c2ccccc2)c2ccccc2o1</smiles>

Figure 4: Chemical structures of Flavonoids<smiles>O=C(O)Cc1ccc(O)c(O)c1</smiles>

Figure 5: Caffeic acid [11]

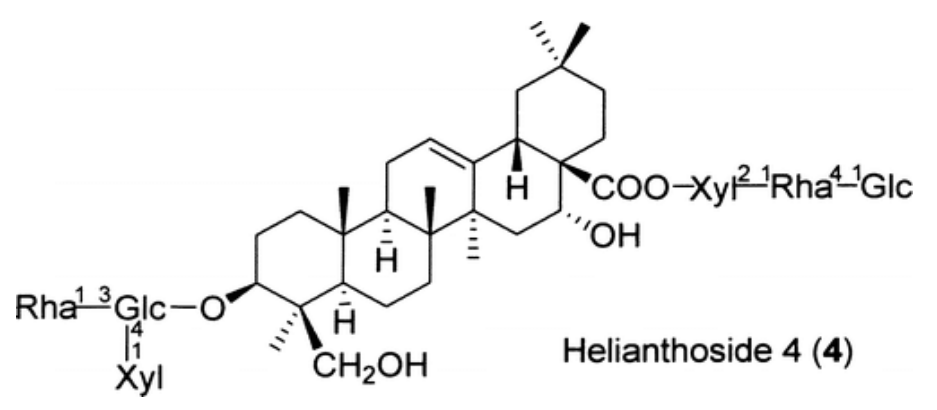

Figure 6: Helianthosides 4(4) [31]

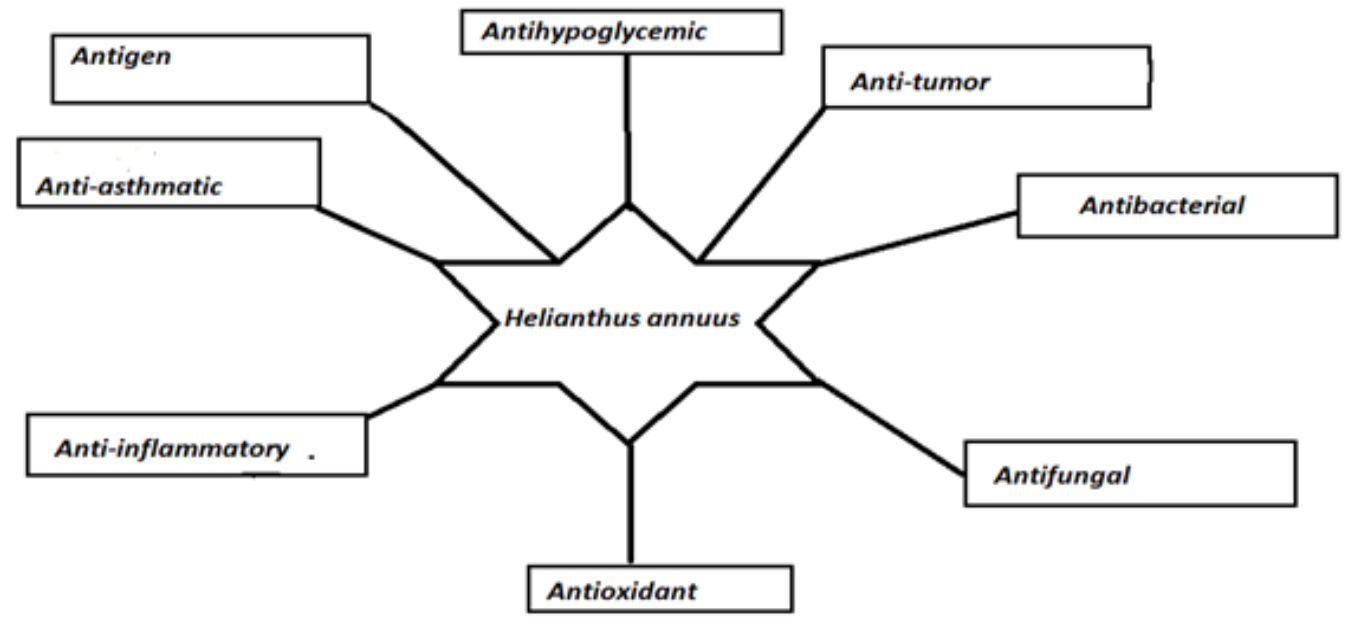

Figure 7: Pharmacological activities of Helianthus annuus 
Table-1. Phytochemicals found in Helianthus annuus.

\begin{tabular}{|c|c|c|}
\hline Name of compounds & Plant part & References \\
\hline Alkaloids & Seeds & {$[35]$} \\
\hline Carbohydrates & Seeds & {$[13]$} \\
\hline Phenolic compound & Florets & {$[16]$} \\
\hline Allelochemicals & Leaves, Stems, Roots & {$[20]$} \\
\hline Saponin & Seeds & {$[35]$} \\
\hline Tannins & Seeds & {$[15]$} \\
\hline Terpenoids & Aerial parts & {$[17]$} \\
\hline Steroids & Seeds & {$[35]$} \\
\hline Flavonoids & Seeds & {$[22]$} \\
\hline
\end{tabular}

Table-2. Some Traditional uses of Helianthus annuus.

\begin{tabular}{|l|l|l|l|}
\hline Traditional use & Plant part & Country & References \\
\hline Cuts, Wounds & Stem & Cochiti(New Mexico) & {$[30]$} \\
\hline Kidneys treatment & Leaves & America & {$[30]$} \\
\hline Fever & Leaves & Russia & {$[10]$} \\
\hline Pulmonary infections & Seeds & Europe & {$[30]$} \\
\hline Bronchiectasis & Flowers and leaves & India & {$[10]$} \\
\hline
\end{tabular}

\section{Other compounds}

It is indicated that from acetone extract of flower disc of Helianthus annuus L. four compounds namely (2R)-2- hydroxyl-N[(2S, 3S, 4R, 10E)-1, 3, 4-trihydroxyicos10-en-2-y1]docosanamide, $\quad(2 \mathrm{R}, 3 \mathrm{R})-2,3-$ dihydroxy-N $\quad[(2 \mathrm{~S}, 3 \mathrm{~S}, 4 \mathrm{R}, 10 \mathrm{E})-1,3,4-$ trihydroxyicos-10-en-2-yl] docosanamide, $\mathrm{N}$ (2-phenylethyl) tetracosanamide, together with a known ceramide, (2R)-N[(2S,3S,4R,8E)- 1-( $\beta$-d-Glucopyranosyloxy) -3,4-dihydroxyoctadec-8-en-2- yl] -2hydroxyhexadecanamide are derived [27].

\section{Ethnomedicinal Uses}

Sunflower plant is a medicinal plant. Different parts of plant are traditionally use for treatment of different ailments. A review of books and papers shows that $H$. annuus is used in local medicine in some Asian and European countries. The $H$. annuиs seeds are use in the treatment of laryngeal, pulmonary infections, bronchial, coughs and colds and in whooping cough. A tincture which is prepared from seed with rectified spirit of wine is very useful for the treatment of ague and fevers [28].

Helianthus tincture is use in the treatment of malarial fever. Mostly leaves are spread on a bed and covered with a cloth, moistened with warm milk after that patient is warped up in it. Perspiration is produced and this procedure is repeated until the fever has ceased. A tincture of the flowers and leaves are used in combination with balsamic in the treatment of bronchiectasis [29].

In Mexico the sunflower is use for food and also believed as medicinal in soothing chest pains. An anthropologist known Charles H. Lange at the University of Texas wrote a reliable home remedy that juice of freshly crushed sunflower stems is use for cuts and other wounds. The juice is mottled abundantly over the wounds and bandaged 
and results in a speedy recovery, with never a case of infection [30].

Researchers from the Johns Hopkins University studied in between 1998 and 2003 in Bangladesh that sunflower oil can protect premature babies from bacterial infections when rubbed onto their skin several times daily. Sunflower oil can also be applied to the face and neck to treat and prevent acne breakouts. The sunflower oil protects cells from cancer-causing radicals as well as preventing infection and diseases. Oil of sunflower is use for acne treatment [31].

\section{Pharmacological Activities of $\boldsymbol{H}$. annuus}

Researcher did a lot of work to investigate the biological or pharmacological activities of $H$. annuus $\mathrm{L}$.

\section{Anti-inflammatory Activities}

Sunflower exhibits anti-inflammatory activity. From an n-Butanol-soluble fraction of a methanol extract of a flower petals of sunflower, two new oleanane-type triterpene glycosides, helianthosides 4(4) (Fig. 6) and 5(5), along with four known triterpene glycosides, helianthosides 1(1), 2(2), 3(3) and B (6) isolated which possess distinct anti-inflammatory activities on 12-Otetradecanoylphorbol-13-acetate induced ear edema in mice. All of the triterpene glycosides exhibit potent inhibitory effects and are more potently inhibit [32].

\section{Anti-asthmatic Activity}

The effect of $H$. annuus L. seed aqueous extract is analyzed on an in vivo antiasthmatic model on ovalbumin induced mice and their lungs are assess by hemotoxylin and eosin staining. By these findings it is conclude that the extract has extensive potential to reduce the asthma [33].

\section{Antioxidant property}

Sunflower plant has excellent anti-oxidant property. The antioxidant capability of the sunflower seed extracts is obtain by chronological extraction with different polarities of solvents by in vitro methods: ferric reducing/antioxidant power, oxygen radical absorbance capacity assays and 2diphenyl-1-picrylhydrazyl radical.It is analyze that the intake of this seed may prevent cancer and other oxidative reaction related diseases [34].

\section{Antigen property}

Different extracts from $H$. annuus exhibit inhibitory effect on Epstein-Barr virus. It is analyze that from the diethyl ether extract of the pollen grains of $H$. annuus following compounds are isolated such as four free triterpene alcohols, eight fatty acid esters of triterpene alcohols, two tochopherol-related compounds, four estolides, three syn-alkane4, 6-diols, 1, 3-dioxoalkanoic acid and one aliphatic ketone along the mixture of free fatty acids and showed inhibitory effects on Epstein-Barr virus and early antigen induced by tumor promoter induction [35].

\section{Antihypoglycemic effects}

Ethanolic extracts of $H$. annuus exhibit antidiabetic potential.Seeds show antihyperglycemic effect in rats. It is detected that the oral administrations of ethanolic extract which contain polyphenols from $H$. annuus $L$. cause a decline in diabetes [36].

\section{Antimicrobial activities}

The antimicrobial activity of methanolic extract of seeds is evaluated from Helianthus annuus L [13]. The polar oil from the seeds of sunflower (Helianthus annuus) shows antimicrobial activity against Staphylococcus epidermis, E. coli, Pseudomonas aeruginosa, Candida albicans, Staphylococcus aureus and Proteus vulgaris [14].

$H$. annuus show better antifungal properties (Table 3). Methanol extracts of $H$. annuus seed posse's antifungal activity against fungal strains which cause various infections [36].

\section{Conclusion}

The sunflower is the center of medicinal values which is used as food and medicine 
worldwide. The pharmacodynamic basis supporting the use of $H$. annuus extracts in ethnomedicinal systems has been established and pharmacological studies have demonstrated the anti-oxidant,antiinflammatory, antitumor, antigen, antipyretic, astringent, cathartic, diuretic, antiasthmatic, stimulant, vermifuge, vulneray purposes and antimicrobial activities and antihypoglycaemic effects of the plant extracts. The significant therapeutic effects seen by $H$. annuus are a result of the presence of an array of phytochemicals which include terpene compounds, carbohydrates, phenols, flavonoids, tannins, alkaloids, saponins, phytosterols, active proteins, fixed oils and steroids. Further illumination of the molecular mechanisms primary the activity of these chemicals is also critical to estimate the possibility of using the plant extracts for future drug development.It may direct the further research on sunflower for some activities for which it is used traditionally.

\section{References:}

1. Fowler MW (2006). Plants, medicines and man. J Sci Food Agr 86(12): 17971804.

2. Owens GL \& Rieseberg LH (2014). Hybrid incompatibility is acquired faster in annual than in perennial species of sunflower and tarweed. $J$ Evol 68(3): 893-900.

3. Dwivedi A \& Sharma GN (2014).A review on Heliotropism plant: Helianthus annuus L. J Pharmacol 3(2): 149-155.

4. Halvorson W \& Guertin, P (2003). Helianthus annuus L. U.S. Geological survey. Southwest desert field station. Sonoran field station. University of Arizona.

5. Putnam DH, Oplinger ES, Hicks DR, Durgan BR, Noetzel DM,.Meronuck RA, Doll JD \& Schulte EE (1990).
Alternate field crops manual: sunflower. extension service.

6. Venktesh A \& PrakashV (1993). Functional properties of the total proteins of sunflower (Helianthus annuus L.) seed-effect of physical and chemical Treatments. J Agr. Food Chem 41(1): 18-23.

7. Lee YH, Song HL, Piao XM, Park KH, Nam SY, Kim IJ, Choi SY, Jang YS \& Kim HS (2010). Variations of seed traits, oil content and fatty acid composition in sunflower accession. Korean J Crop Sci 55: 245-252.

8. Izquierdo NL, Aguirrezábal, Andrade F \& Pereyra V (2002). Night temperature affects fatty acid composition in sunflower oil depending on the hybrid and the phonological stage. Field Crop Res 77: 115-126.

9. Baydar H \& Erbas S (2005). Influence of seed development and seed position on oil, fatty acids and total tocopherol contents in sunflower (Helianthus annuus L.). Turk J Agric For 29: 179186.

10. Arshad M \& Amjad M (2012). Medicinal use of Sunflower oil and present status of sunflower in Pakistan. Sci Technol. Dev 2012; 31 (2): 99-106.

11. Ibrahim TA \& Ajongbolo KF (2014). "Phytochemical screening and antimicrobial activity of crude extracts of Basella alba and Helianthus annuus on selected food pathogens. $J$ Microbiol Biotechnol 3.2: 27-31.

12. Boriollo MF, Souza LS, Resende MR, Silva TA. Oliveira N, Resck MC \& Fiorini JE (2014).Nongenotoxic effects and a reduction of the DXR-induced genotoxic effects of Helianthus annuusLinné (sunflower) Seeds revealed by micronucleus assays in mouse bone marrow. $B M C$ 
complementary and Alternative medicine. 14(1): 121.

13. Düsterhöft EM, Posthumus MA \& Voragen GJ (1992). Non-starch polysaccharides from Sunflower (Helianthus annuus) meal and palmkernel (Elaeisguineensis) mealinvestigation of the structure of major polysaccharides. $J$ Sci Food Agr 59: 151-160.

14. Subashini R \& Rakshitha SU (2012). Phytochemical screening, antimicrobial activity and in vitro antioxidant investigation of methanolic extract of seeds from Helianthus annuus L. Chem Sci Rev and Lett 1(1): 30-34.

15. Aziz FM, Darweesh MJ, Rahi FA \& Saeed RT (2014) In vivo and in vitro studies of a polar extract of Helianthus annuus (Sunflower) seeds in treatment of Napkin Dermatitis. Int J Pharm Sci Rev Res 24(2): 1-3.

16. Liang Q, Cui J \& Zhao G (2013). Florets of Sunflower (Helianthus annuus L.): Potential new sources of dietary fiber and phenolic acids. J Agr Food Chem 61(14): 3435-3442.

17. Macías FA, Lopez A, Varela RM, Torres A \& Molinillo JMG (2008). Helikauranoside A new bioactive diterpene. J Chem Ecol 34(1): 65-69

18. Spring O \& Hager A (1982B). Inhibition of elongation growth by two sesquiterpene lactones isolated from Helianthus annuus L. 2006; Planta 156(5): 433-440.

19. Spring O, Albert K \&, HagerA (1982). Three biologically active heliangolides from Helianthus annuus. Phytochem 21(10): 2551-2553.

20. Kamal J (2011). Quantification of alkaloids, phenols and flavonoids in Sunflower (Helianthus annuus L.). Afr J Biotechnol 10(16): 3149-3151.
21. Macías FA, Molinillo JMG, Torres A, Varela RM \& Castellano D (1997). Bioactive flavonoids from Helianthus annuus cultivars. Phytochem 45(4): 683-687.

22. Rao YK, Rao CV, Kishore PH \& Gunasekar D (2001). Total synthesis of Heliannone A and (R,S)-Heliannone B, two bioactive flavonoids from Helianthus annuus cultivars. J. Nat. Prod 64 (3): 368-369.

23. Pickardt C, Weiszb GM, Eisnera P, Kammererb DR, Neidhartb S \& Carle $R$ (2011). Processing of low polyphenol protein isolates from residues of Sunflower seed oil production. Procedia Food Sci 1: 1417-1424.

24. Glenn W \& Chapman Jr (1987). A proteinaceous competitive inhibitor of lipase isolated from Helianthus annuus seeds. Phytochem 26(12): 3127-3131

25. Giudici AM, Regente MC \& Canal L (2000). A potent antifungal protein from Helianthus annuusFlowersis: A trypsin inhibitor. Plant Physiol Biochem 38(11): 881-888.

26. Salgın, Uğur, Onur D \& Ayla Ç (2006). Extraction of sunflower oil with supercritical $\mathrm{CO}_{2}$ : Experiments and modeling." J Supercrit Fluids 38 (3): 326-31.

27. Mikolajczak KL, Smith CR \& Wolff IA (1970). Phenolic and sugar components of Armavireo variety Sunflower (Helianthus annuus) seed meal. J Agri Food Chem 18 (1): 27-32.

28. Suo M \& Yang J (2014). Ceramides isolated from Helianthus annuus $\mathrm{L}$. Helvetica Chimica Acta 97(3): 355360.

29. Imran M, Hussain A, Gurmani ZA, Zahid MS \& Khan S (2008). Cultivation of sunflower and its 
utilization in livestock. Science $J$ Technol Dev 27: 1-2.

30. Heiser CB. Jr (1976). The sunflower. University of Oklahoma Press 198 pp.

31. Ukiya M. (2007). Triterpene glycosides from the flower petals of sunflower (Helianthus annuиs) and their anti-inflammatory activity $J \mathrm{Nat}$ Prod 70.5: 813-816.

32. Heo JC, Woo SU, Kweon M A, Park JY, Lee HK, Son M, Rho JR \& Lee SH (2008). Aqueous Extract of The Helianthus aпnииs seed alleviates asthmatic symptoms In vivo. Int $\mathrm{J} \mathrm{Mol}$ Med 21(1): 57-61.

33. Giada MD \& Mancini FJ (2009). Antioxidant capacity of the striped Sunflower (Helianthus annuus L.) seed extracts evaluated by three In vitro methods. Int J Food Sci Nutr 60(5): 395-401.
34. Ukiya M, Akihisa T, Tokuda H, Koike K, Takayasu J, Okuda H, Kimura Y, Nikaido T \& Nishino H (2003). Isolation, structural elucidation and inhibitory effects of terpenoid and lipid constituents from Sunflower pollen on Epstein - Barr virus early antigen induced by tumor promoter, TPA. $J$ Agr FOOD Chem. 51(10): 2949-57.

35. Saini SNI \& Sharma S (2013). Antidiabetic Effect of Helianthus annииs L., Seeds ethanolic extract in streptozotocinnicotinamide induced type 2 Diabetes Mellitus. Int J Pharm Pharm Sci 25(2): 382-387.

36. Subashini R, Mahesh V, Kavitha A, Geethanjali B \& Umamaheshwari S (2013). Comparative evaluation of antimicrobial activity of selected three herbal plants extract with digital Image processing. EJB I9 (2): 14-26. 